\title{
Rehabilitation of the esthetic zone using multiple adjacent individual implant-supported restorations: Where are the limits?
}

\author{
Rehabilitación de la zona estética mediante múltiples restauraciones \\ individuales adyacentes apoyadas por implantes: ¿cuáles son los límites?
}

Guillermo Bernal DulceY' ${ }^{1}$ RAfael Murgueitioº ${ }^{2}$ Héctor Ríos ${ }^{3}$

\begin{tabular}{l} 
Professor, Universidad Javeriana, Bogota, Colombia. Adjunct Professor, Loma Linda University, Loma Linda, California. Private Practice, \\
Bogota, Colombia \\
2 Professor, School of dentistry UNICOC, School of dentistry Universidad del Valle, Cali, Colombia. Private Practice, Cali, Colombia \\
Department of Periodontics and Oral Medicine, School of Dentistry, University of Michigan, Ann Arbor, MI, USA \\
\hline
\end{tabular}

ABSTRACT

Rehabilitation of the partially edentulous anterior maxilla is considered one of the most difficult challenges for the restorative dentist due to the esthetic, functional and psychological implications. Implant-supported restorations provide an appealing treatment alternative that responds to today's patient expectations. The gold standard for this scenario has been the use of an implant-supported fixed partial denture with pontics that masks the soft tissue deficiencies, with acceptable esthetic results. However, nowadays patients are looking for individual single crowns since they believe that this type of restorations resemble the natural dentition, are easy to clean and floss. From the dentist perspective, they are easy to maintain and in

Keywords: dental implants, partial edentulous, screw retained crown case of prosthetic complications they can be repaired or changed without compromising the adjacent restorations. Three parameters have been identified that could guide the decision-making process when multiple adjacent implant supported restorations (MAISR) are selected as the treatment of choice: 1) Smile line 2) Inter-implant distance and tooth-implant distance 3) Patient's expectations and ability to clean.

\section{RESUMEN}

La rehabilitaci $\mathrm{n}$ del maxilar anterior parcialmente ed ntulo se considera uno de los retos $\mathrm{m}$ s dif ciles para el dentista restaurador debido a las implicaciones est ticas, funcionales y psicol gicas. Las restauraciones apoyadas por implantes proporcionan una alternativa de tratamiento atractiva que responde a las expectativas actuales de los pacientes. El patr $\mathrm{n}$ de referencia en este contexto ha sido el uso de una pr tesis parcial fija con implantes con p nticos para enmascarar las deficiencias de tejido blando, el cual ha tenido resultados est ticos aceptables. Sin embargo, hoy en $\mathrm{d}$ a los pacientes est $\mathrm{n}$ buscando coronas individuales ya que creen que este tipo de restauraciones se asemejan a la dentici $\mathrm{n}$ natural y son $f$ ciles de limpiar con cepillado e hilo dental. Desde la perspectiva del dentista, son $f$ ciles de

Palabras clave: mantener y en caso de complicaciones prot sicas pueden ser reparadas o cambiadas sin comprometer implantes dentales, ed ntulo parcial, corona retenida por tornillo

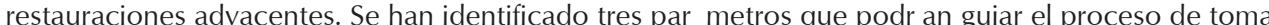
de decisiones cuando se seleccionan varias restauraciones compatibles con implantes adyacentes como el tratamiento de elecci n: 1) L nea de sonrisa 2) Distancia entre implantes y distancia de implante dental 3) Las expectativas del paciente y la facilidad de limpieza.

Submitted: July 17/2018 - Accepted: October 9/2018

How to quote this article: Bernal-Dulcey G, Murgueitio R, R os H. Rehabilitation of the esthetic zone using multiple adjacent individual implant-supported restorations: Where are the limits? Rev Fac Odontol Univ Antioq. 2019; 30(2): 264-271. DOI: http: //dx.doi.org/1017533/udea.rfo.v30n2a11 


\section{INTRODUCTION}

One of the most important esthetic parameters with anterior implant-supported restorations is the achievement of an ideal soft tissue outcome relative to volume, position and color. ${ }^{1-3}$ This case is often more feasible when there is a single implant restoration adjacent to natural dentition. ${ }^{4}$ In the presence of multiple missing teeth adjacent to each other, in which immediate placement is not possible or has not been previously performed, it is common to see bone volume deficiencies and soft tissue inadequacies. ${ }^{5}$ This complex common clinical scenario makes ideal implant placement very difficult and the desired esthetic outcome unpredictable. This situation is commonly overcome by 1 ) the use of bone grafting, guided bone regeneration and/or soft tissue regeneration ${ }^{7,8}$ or 2) the use of an implant-supported fixed partial denture with pontics that masks the soft tissue deficiencies. ${ }^{9}$ The use of pontics can provide an excellent alternative but can also present limitations, such as alveolar ridge resorption, limitation for the patient who wants to have individual restorations to facilitate oral hygiene, and in the case of a technical complication, it may require a complete replacement of the prostheses. ${ }^{10,11}$

When using multiple adjacent implantsupported restorations (MAISR), maintaining or reestablishing the inter-implant soft tissue is unpredictable and often leads to inadequate open embrasures. However, patients with fixed or removable partial dentures frequently ask for the probability to have individual restorations, or even better, implant-supported restorations because they presume that this type of restorations may resemble natural dentition.

The aim of these case reports is to highlight some limits in order to decide between fixed partial dentures with pontics or MAISR in the esthetic zone. Three parameters have been identified to guide the decisionmaking process: 1) Smile line 2) Interimplant distance and tooth-implant distance 3) Patient's expectations and ability to clean.

The smile line is commonly divided into three categories: high, average, and low, depending on the amount of tooth and soft tissue exposed during the maximal smile. ${ }^{12,13}$ The smile line is considered the first parameter in the decision-making process when MAISR is the selected treatment. In cases of high smile line, this option is contraindicated, since an uneven margin or a papilla discrepancy will be immediately noticeable. Cases with average smile in elderly population, where esthetics is not an issue and manual dexterity is compromised by MAISR, could be considered. The ideal scenario for this type of restorative treatment is the patient with low smile line where any soft tissue discrepancy or deficiency is rarely noticeable.

Regarding the inter-implant distance, it should be no less than $3 \mathrm{~mm}$, and the tooth-implant distance no less than $1.5 \mathrm{~mm}$ to preserve the interproximal bone and obtain an adequate papillae volume and contour. ${ }^{14-17}$ When fixed or removable partial dentures in the anterior premaxilla are present, normally horizontal and vertical dimensions of the residual ridge are reduced. In this situation, multiple adjacent implant placement is contraindicated since the bone dimension does not allow appropriate inter-implant distance where the implants platforms are located too close to each other or to an adjacent natural root, which in turn will complicate the restorative procedures and increase the risk for interproximal tissue loss.

In case of multiple teeth extractions with immediate implant placement and bone and 
soft tissue guide regeneration, MAISR can be a viable alternative to minimize alveolar ridge resorption. This approach, with an appropriate surgical and prosthetic planning and design, allows proper implant placement, which leads to adequate emergence profile, gingival zenith location, proximal embrasures and subsequent papillae formation. ${ }^{20}$

When choosing a dental treatment plan, not only clinical factors must be considered. Patient expectations have to be clearly identified and included in the decisionmaking process, ${ }^{21}$ i.e. number of implants, financial conditions, future complications solving, and ability to clean and floss. When people grow old, they occasionally decrease their manual dexterity and become care dependent, and it usually becomes increasingly difficult to maintain oral health. Individual restorations are easier to maintain using conventional brushing and flossing techniques. Conversely, fixed partial dentures make it more difficult to perform oral hygiene and professional maintenance.

Besides, a direct correlation between periimplantitis and prosthetic design that limits the performance of an ideal oral hygiene has been found. ${ }^{22}$

\section{CLINICAL CASE DESCRIPTIONS}

\section{Case 1}

General description: twenty-four-year-old male, missing teeth 12, 11, 21, 22, 23 in a sports accident. Average smile line. Alveolar ridge defect Seibert 3.

Chief complaint: to replace his teeth as natural as possible.

Treatment summary: guide bone and soft tissue regeneration. Screw retained fixed all ceramic partial prostheses.

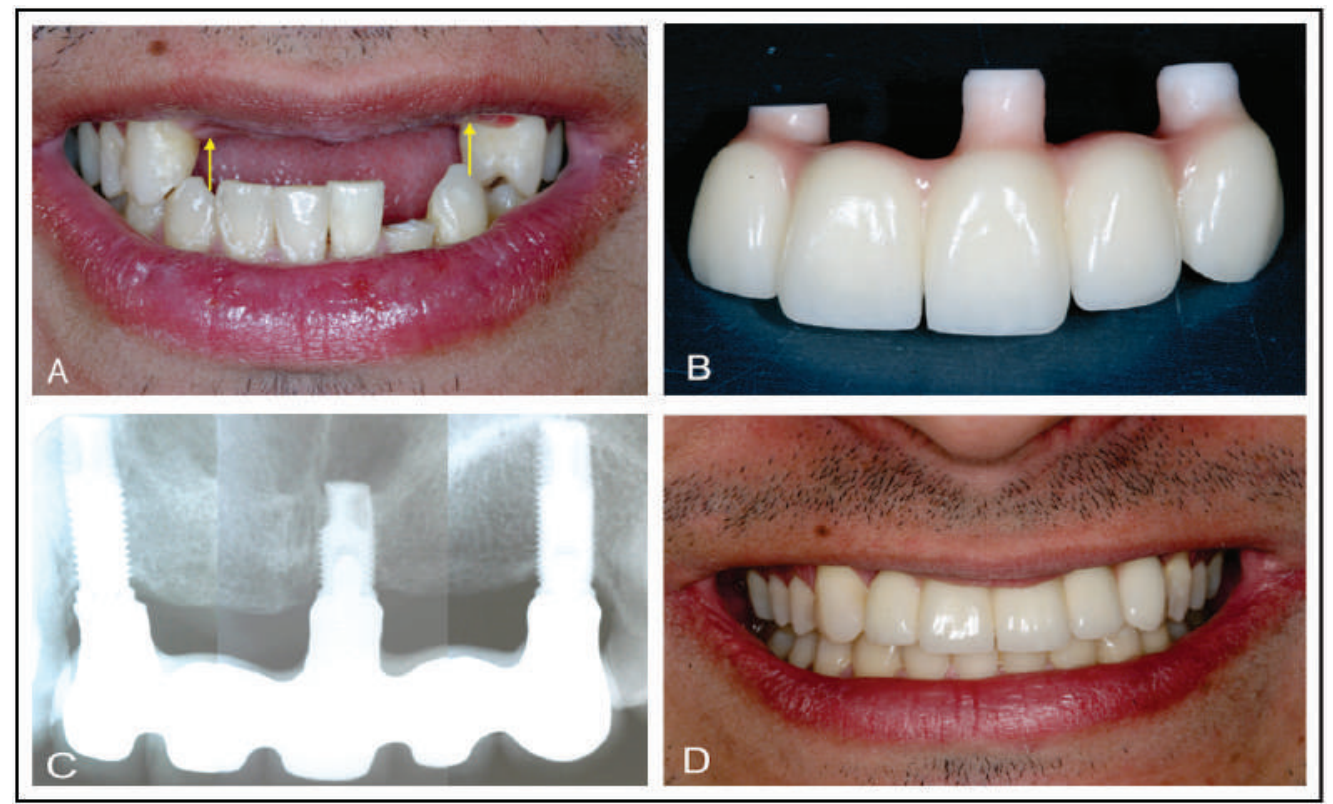

Figure 1. Case 1. A. Loss of 5 anterior teeth, partially exposed residual alveolar process, average smile. B. Screw retained fixed partial dental prostheses with pink ceramic papilla simulation. C. Radiographic control. D. Smile showing the pink ceramic papilla simulation. 


\section{Case 2}

General description: 46-year-old woman who, lost her anterior teeth because fractures and caries, had a provisional fixed partial denture with pontics in zone of 12, 11, 21 and 22. Alveolar ridge defect Seibert 3. Decreased vertical dimension of occlusion. Low smile line.
Chief complaint: to have individual implant supported crowns.

Treatment summary: orthodontic treatment to level the occlusal plane, restitution of the vertical dimension of occlusion with ceramic crowns in the posterior teeth, bone and soft tissue regeneration of the esthetic zone. Four cement retained MAISR in zone of 12 , 11,21 and 22 and individual all ceramic crowns in the abutment teeth.

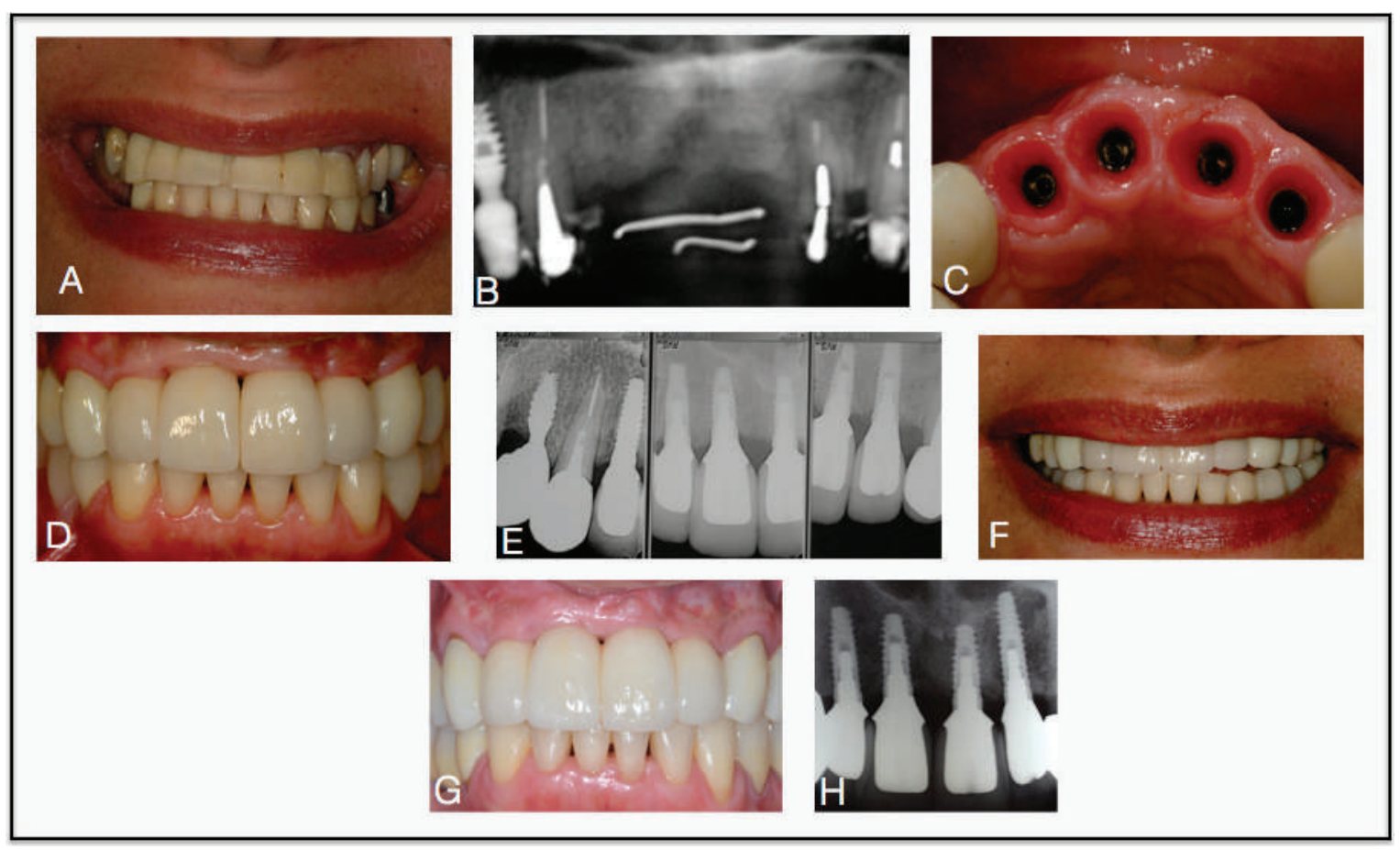

Figure 2. Case 2. A. Low smile line, unaesthetic anterior provisional fixed partial prostheses. B. Initial radiographic control. C. Adequate inter-implant and implant-teeth distance after guide bone and tissue regeneration. D. (MAISR) all ceramic screwretained crowns. E. Base line radiographic control. F. Final smile. G and H. Five-year clinical and radiographic follow-up.

\section{Case 3}

General description: 46-year-old male, with 6 units fixed partial dental prostheses with pontics replacing teeth number 12,11 and 21.

Chief complaint: he doesn't want to have a fixed partial denture. He expected to receive individual implant crowns to feel more confidence and for easy flossing.
Treatment summary: He received orthodontics of his lower teeth to improve the anterior teeth relation and to close diastemas, bone and soft tissue regeneration of the anterior zone. Three all-ceramic MAISR screw-retained and individual allceramic crown in the abutment teeth. 


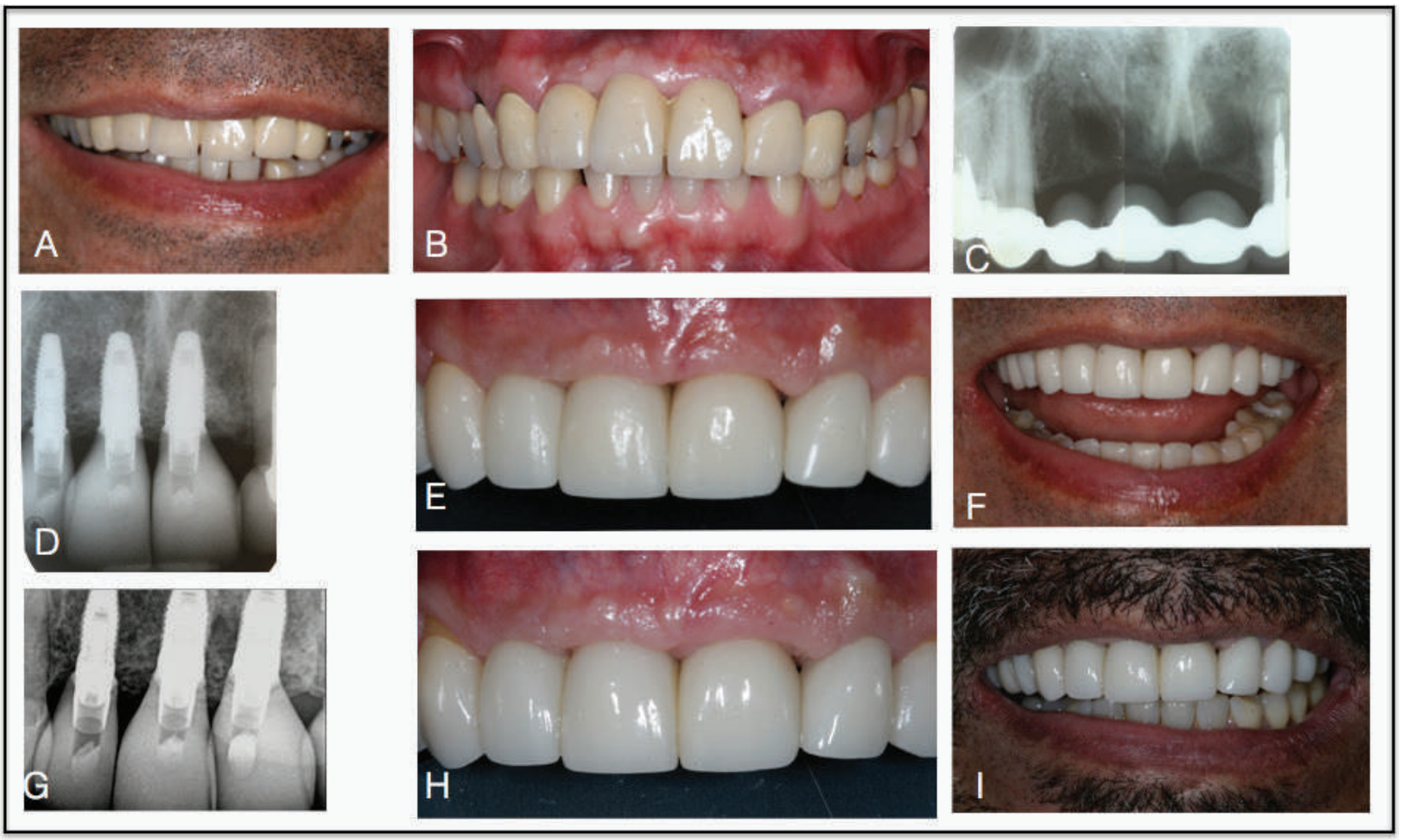

Figure 3. Case 3. A. Low smile line. B. Metal ceramic fixed partial denture. C. Initial periapical radiograph. D. Radiographic control at baseline. E. Three adjacent individual implant-supported restorations screw-retained metal free ceramic crowns at baseline. F. Smile line at base line. G, H and I. Two years follow up.

\section{DISCUSSION}

In the decision-making process between implant-supported fixed partial dentures or MAISR to replace two or more adjacent teeth in the esthetic zone, the smile line should be the first parameter to consider. Patients with a low smile line may be candidates for individual implant-supported restorations for the replacement of multiple missing teeth in esthetic zone (Cases 2 and 3) (Figures 2 and 3). However, in patients with a high or average smile, implant-supported fixed partial dentures with pontics instead of individual implants are considered the best option, ${ }^{8}$ since a more predictable esthetic result can be achieved if fewer implants are placed with fixed partial dentures. Also, this approach allows a better esthetic outcome at the gingival level either with ovoid pontics or pink ceramics to mimic the gingival papillae (Case 1) (Figure 1).

It is generally accepted that an inter-implant distance of $3 \mathrm{~mm}$ and an implant-to-tooth distance of $1.5 \mathrm{~mm}$ offers a biological and prosthetic advantage that would favor an optimal esthetic outcome. ${ }^{21}$ Some evidence presents certain flexibility regarding this parameter and is supported by some existing surgical protocols and variations on implant designs. This is the case with the platformswitching concept, which allows some prosthetic flexibility by compensating for the lack of space and increase in soft tissue thickness between the implants. ${ }^{22-24}$ However, this concept should be handled with caution; while some researchers have demonstrated 
it with animal studies and a few case reports, others suggest that there are other factors which minimize the crestal bone loss around dental implants, i.e. 3D-implant positioning, width of alveolar ridge and control of micro motion at the implant-abutment interface. ${ }^{25}$ However, in case 3, the implant in the zone of 21 tooth position was much closer to the implant in the zone of tooth 11 position and much far from tooth number 22, leading to inadequate papilla between implants and a big interproximal embrasure between implant and tooth.

Therefore, our recommendation is to avoid the use of contiguous implants for the highly esthetic case whenever it is not possible to establish a proper inter-implant and/ or implant-tooth relationship. However, when the clinical case is properly planned, beginning at the pre-surgical stage including hard and soft tissue generation, adequate diagnostic wax up to determine the feasibility of individual restorations, restricted surgical guides and adequate implant supported provisional restorations will allow to obtain adequate results (Figures 2 and 3).

It is important to emphasize that, in all situations, the emergence profile of the restoration must be designed to enable biological contours that must preserve longterm soft tissue stability and favor proper access to facilitate maintenance.

Regarding patient expectations between fixed and individual restorations, there is no doubt that they will prefer individual restorations. Also, oral hygiene is easier to perform with individual restorations because fixed partial dentures require other elements such as threaded floss or interproximal brushes. Moreover, more dexterity is required for hygiene when having fixed partial dentures, which becomes increasingly difficult over the years. Serino and Strom reported that $48 \%$ of implants presenting peri-implantitis were those with no accessibility/capability for proper oral hygiene $(65 \%$ positive predict value), with respect to $4 \%$ of the implants with accessibility/capability $(82 \%$ negative predict value).

Finally, it is recommended to perform wellcontrolled clinical studies associated with quality of life assessments, which are focused on patient satisfaction in partially edentulous cases that have been restored either with individual implant-supported restorations or fixed partial dentures in the esthetic zone.

\section{CONCLUSIONS}

A treatment option has been presented to assist the clinician in the decision-making process to diagnose and formulate an adequate treatment plan for the partially edentulous patient who requests multiple individual adjacent implant-supported restorations in the esthetic zone. This approach provides parameters that will highlight the presence of different levels of clinical complexity, including compromised situations where an alternative treatment such as implant-supported fixed partial dentures will be more feasible.

\section{CONFLICT OF INTEREST}

The authors declare that they have no conflict of interest. 
Rehabilitation of the esthetic zone using multiple adjacent individual implant-supported restorations: Where are the limits?

\section{CORRESPONDING AUTHOR}

\author{
Dr. Rafael Murgueitio \\ School of Dentistry UNICOC and Escuela \\ de Odontolog a Universidad del Valle
}

\author{
rmurgueitio@unicoc.edu.co, \\ rafael.murgueitio@correounivalle.edu.co \\ Carrera 35A \# 3b-65 \\ Cali, Colombia
}

\section{REFERENCES}

1. Kay H. Classification of altered dental esthetics. Int J Periodontics Restorative Dent. 2002; 22(1): 85-94.

2. Pjetursson BE, Br gger U, Lang NP, Zwahlen M. Comparison of survival and complication rates of toothsupported fixed dental prostheses (FDPs) and implant-supported FDPs and single crowns (SCs). Clin Oral Implants Res. 2007; 18(Suppl 3): 97-113. DOI: https://doi.org/10.1111/j.1600-0501.2007.01439.x

3. Belser U, Grutter L, Vailati F, Bornstein MM, Weber HP, Buser D. Outcome evaluation of early placed maxillary anterior single-tooth implants using objective esthetic criteria: A cross-sectional, retrospective study in 45 patients with a 2- to 4-year follow-up using pink and white esthetic scores. J Periodontol. 2009; 80(1): 140-51. DOI: https://doi.org/10.1902/jop.2009.080435

4. Pieri F, Aldini NN, Marchetti C, Corinaldesi G. Influence of implant-abutment interface design on bone and soft tissue levels around immediately placed and restored single-tooth implants: a randomized controlled clinical trial. Int J Oral Maxillofac Implants. 2011; 26(1): 169-78.

5. Spear F. Implants or pontics: decision making for anterior tooth replacement. J Am Dent Assoc. 2009; 140(9): 1160-6. DOI: https://doi.org/10.14219/jada.archive.2009.0345

6. Seibert J. Lindhe J: Esthetics in periodontal therapy. In: Lindhe J, Karring T, Lang NP (eds). Clinical periodontology and implant dentistry. 3 ed. Munksgaard, Copenhagen: Wiley-Blackwell, 1997. pp. 647-81.

7. Buser D, Ingimarsson S, Dula K, Lussi A, Hirt HP, Belser UC. Long-term stability of osseointegrated implants in augmented bone: a 5-years prospective study in partially edentulous patients. Int J Periodontics Restorative Dent. 2002; 22(2): 108-17.

8. Aghaloo T, Moy PK. Which hard tissue augmentation techniques are the most successful in furnishing bony support for implant placement? Int J Oral Maxillofac Implants. 2007; 22(Suppl): 49-70.

9. Vailati F, Belser UC. Replacing four missing maxillary incisors with regular- or narrow-neck implants: analysis of treatment options. Eur J Esthet Dent. 2007; 2(1): 42-57.

10. Goodacre CJ, Bernal G, Rungcharassaeng K, Kan JY. Clinical complications with implants and implant prostheses. J Prosthet Dent. 2003; 90(2): 121-32. DOI: https://doi.org/10.1016/S0022-3913(03)00212-9

11. Walton JN, MacEntee MI. Problems with prostheses on implants: a retrospective study. J Prosthet Dent. 1994; 71(3): 283-8. DOI: https://doi.org/10.1016/0022-3913(94)90468-5

12. Dong JK, Jin TH, Cho HW, Oh SC. The esthetics of the smile: a review of some recent studies. Int J Prosthodont. 1999; 12(1): 9-19.

13. Passia N, Blatz M, Strub J. Is the smile line a valid parameter for esthetic evaluation? A systematic literature review. Eur J Esthet Dent. 2011; 6(3): 314- 27.

14. Tarnow DP, Cho SC, Wallace SS. The effect of inter-implant distance on the height of inter-implant bone crest. J Periodontol. 2000; 71(4): 546-9. DOI: https://doi.org/10.1902/jop.2000.71.4.546 
Rehabilitation of the esthetic zone using multiple adjacent individual implant-supported restorations: Where are the limits?

15. Nevins M, Nevins M, Gobbato L, Lee HJ, Wang CW, Kim DM. Maintaining interimplant crestal bone height via a combined platform-switched, Laser-Lok implant/abutment system: a proof-of-principle canine study. Int J Periodontics Restorative Dent. 2013; 33(3): 261-7. https://doi.org/10.11607/prd.1773

16. Rodriguez-Ciurana X, Vela-Nebot X, Segal -Torres M, Calvo-Guirado JL, Cambra J, Mendez-Blanco V, et al. The effect of interimplant distance on the height of the interimplant bone crest when using platformswitched implants. Int J Periodontics Restorative Dent. 2009; 29(2): 141-51.

17. Romanos GE, Javed F. Platform switching minimises crestal bone loss around dental implants: truth or myth? J Oral Rehabil. 2014; 41(9): 700-8. DOI: https://doi.org/10.1111/joor.12189

18. Mankoo T. Maintenance of interdental papillae in the esthetic zone using multiple immediate adjacent implants to restore failing teeth-a report of ten cases at 2 to 7 years follow-up. Eur J Esthet Dent. 2008; 3(4): 304-22.

19. Avila G, Galindo-Moreno P, Soehren S, Misch CE, Morelli T, Wang HL. A novel decision-making process for tooth retention or extraction. J Periodontol. 2009; 80(3): 476-91. DOI: https://doi.org/10.1902/ jop.2009.080454

20. Serino G, Ström C. Peri-implantitis in partially edentulous patients: association with inadequate plaque control. Clin Oral Implants Res. 2009; 20(2): 169-74. DOI: https://doi.org/10.1111/j.1600-0501.2008.01627.x 